\title{
ELECTRICITY SECTOR REALITY, ECONOMIC SECURITY AND NATIONAL DEVELOPMENT IN NIGERIA: AN ELITE THEORY DIMENSION
}

\author{
Remi C. Okeke ${ }^{1, a^{*}}$ and Florence C. Agbodike ${ }^{2, b}$ \\ ${ }^{1}$ Department of Public Administration and Local Government, University of Nigeria, Nsukka \\ ${ }^{2}$ Department of Public Administration, Nnamdi Azikiwe University, Awka, Nigeria \\ Corresponding Email: ${ }^{a}$ remiokeke@gmail.com, ${ }^{b}$ agbodikef@yahoo.com
}

\section{Keywords: Electricity Sector, Economic Security, National Development, Nigeria}

\begin{abstract}
The electricity sector is an immensely critical component of the equations in a $21^{\text {st }}$ century economy. Economic security on the other hand is the essence of national development. The crucial question in this study therefore borders on the extent to which the electricity sector in Nigeria positively relates to economic security and how these variables ultimately link with national developmental dreams in this nation-state. We have made use of secondary sources of data and the elite theoretical framework in the conduct of the study. The methodology of the study is the critical mode of research. Our findings indicate that there are immense weak-linkages between Nigeria's electricity sector reality, economic security and national developmental aspirations in the country. And this is principally (un)driven by elite insensitivity. The paper emphasizes that a critical leadership challenge in Nigeria hinges on the appreciation of the import of these linkages by current and subsequent generations of national development planners in the Nigerian state.
\end{abstract}

\section{INTRODUCTION}

The history of electricity in Nigeria dates back to 1896 when electricity was first produced in Lagos, just fifteen years after its introduction in England [1]. Electricity has accordingly been in existence in Nigeria for more than 100 years, with various reforms of the electricity sector. However, its development and availability to Nigerians have been a dilemma (sic) [2]. We interpret the occasioning quandary in this study, as elite dilemma. And it follows therefore that economic security has been in danger in Nigeria, as electricity access is an important factor, which speeds up development in most economies of the world [2]. Indeed, electricity or electrical energy plays a very important role in the socio-economic and technological development of a state and indeed, every nation [1]. Without electricity, mass production of goods becomes virtually impossible. While erratic supplies of electricity disrupt production, voltage fluctuations, negatively affect the durability of machines [5]. In this regard, the World Economic Forum [6] highlights that only half of the Nigerian population has access to electricity (only 10\% in rural areas), with power shortages affecting the quality of electricity for those who do receive it. Therefore, despite Nigeria being one of the largest primary energy producers in the world, it still struggles to generate adequate electricity for its teeming population and to support its economy [7]. Awosope [8] further opines that the current status of electricity generated in Nigeria, with regard to its population, is grossly inadequate.

Over the years, many studies have been conducted and papers written by scholars who have decried the poor state of the Nigerian electricity sector [9]. Research has also shown that many households are not able to access electricity, despite its existence in the country for over a century. $[9,10]$. The technical state of the nation's electricity distribution infrastructure has also been studied $[9,11]$. However, the elite dimension to the crises of electricity-supply in the country has not been given adequate scholarly attention, more so the linkages among the elite factor, economic (in)security and national development in the country. Economic security and national development are interwoven. In this study, we interrogate the elite factor in electricity sector reality, economic security and national development in Nigeria. Invariably, the theoretical framework of the study is 
the elite theory. The specific focal point is the political elite in Nigeria. The methodology of the study is the critical mode of research.

\section{CONCEPTUAL ELUCIDATION}

Electricity Sector. We embark on the conceptual elucidation of electricity sector in this section, in order to properly focus this study and underscore our specific interest on electricity. In other words, we do not intend in this work, to fully delve into the comparable concepts of energy sector or power sector or some sorrounding allusions to certain departments of government and their dysfunctionalities. By the electricity sector in Nigeria therefore, we refer to the economic divide of the country where the activities that lead to the generation, transmission, distribution or marketing of electricity (for industrial, commercial, public or residential uses) are undertaken. In this conceptualization, a critical highlight is placed on the position of private generating sets as sources of electricity in Nigeria. The electricity sector in this regard also derisively touches upon the chaos generated by the usage of the ubiquitous personal generating sets in the country.

Economic Security. The concept of economic security is prone to uneasy interpretation. Much of the existing empirical research adopts a common, though often implicit definition of economic security: the degree to which individuals are protected against hardship-causing economic losses [22]. Yet there is much less agreement on how to translate this general definition, into specific domains or how to conceive of the interplay of multiple economic risks, and even less, on how to measure the actual extent of protection that people enjoy [22]. According to Bonoli [23] economic security can be understood as the degree to which individuals are protected against the risk of finding themselves without an income or with an income that is not sufficient to guarantee them a dignified standard of living [23]. In more formal terms, economic security could be defined as $1-p$, where $p$ is the probability of experiencing subjectively defined poverty [23]. It is a wider but, at the same time, a more precise definition of the objective of social protection than the alternatives that are typically found in the literature, the most common one being welfare. Economic security essentially concerns access to income streams. [23]. Consequently, it is not necessarily the responsibility of the state to provide economic security for the citizens. It is however plausible to assume that the templates for economic security should be feely available to all adult citizens. Economic security as a concept in this study agrees with the orthodoxy: the degree to which individuals are protected against hardship-causing economic losses.

National Development. But what is development? Development as a concept has been described as a victim of definitional pluralism [24]. And we intend to avoid in our elucidations, such unhelpful pluralisms. It has further been contended that the concept of development seems to be in a state of flux since the end of the Second World War [24]. Despite the multiplicity of definitions (the high density of the flux), development in the social sciences connotes positive outlook in the well-being of man. It alludes to the comfort and security of citizens, and is often denoted as human-centered. National on the other hand refers to a whole nation and invariably national development refers to the overall development of a country or nation [24]. National development in this study therefore refers to the self-evident comfort and security of the predominant number of citizens in a nation-state.

Elite Theory. According to Okeke [18], Higley [14] highlights that elite theory's origins lie most clearly in the writings of Gaetano Mosca [15], Vilfredo Pareto [16] and Robert Michels [17]. It has however, also been posited that perhaps, the classic expression of elite theory can be found in C. Wright Mills's The Power Elite [18, 12]. Higley [14] in Okeke [12], further posits that elite theory derives from a fundamental and universal fact of social life, namely, the absence in any large collectivity of a robust common interest. In large collectivities therefore, common interest is minimal and must always be supplemented by authoritative decisions that dissenters and opponents dare not or find it inexpedient to resist $[14,12]$. Common interest is even more limited as regards the detailed features of any large collectivity's functioning. Its operations involve day-to-day decisions and, thus, allocations and re-allocations of tasks and statuses. Merely for a large 
collectivity to survive, intelligent and objective decisions that transcend individual interests must regularly be taken [12]. However, there can seldom be any firm consensus among a collectivity's members about the rightness of these decisions. This is partly because only a few are in positions that afford a relatively comprehensive view of the collective effort and its present location in time and space, relative to its goals [12, 14].

According to Arowolo and Aluko [19], in Okeke [12], the elite theory is a philosophical explanation of the role of the leadership in governance as it affects public policy, including all socioeconomic and political matters. Elites accordingly, dominate the formal institutions of government and are a determining factor in governance and decision-making processes. Elites are the decision makers in the society whose power is not subject to control by any other body in the society $[12,19]$. The elite theory postulates that public policy reflects the values and preferences of the elite rather than demands of the masses. The elite consist of those few individuals who wield powers and hold leading positions in the strategic aspects of society. The majority, the masses, only obeys and are guided, controlled and governed by the few. Many of the elites do not hold formal or legal authoritative powers but are rather behind the scene, teleguiding and manipulating overt political and policy actions $[20,19,12]$.

The elite theory directs attention to the source of policy flow and whose interests public policies serve. The theory attempts a realistic explanation of the source of policy by predicating it on the elite rather than the masses. Elites are capable of setting the tone of society by coming out with policies of their choice. Hence, the level of stability and progress achieved in any society is a function of elites' initiatives [19, 12]. Accordingly, the Nigerian elites make, interpret and implement laws that govern the society [12]. Over the years therefore, the spheres of elite activity [21] have expanded to reach finance, business, bureaucracy, the military, education and different other areas [12].

\section{ELECTRICITY SECTOR REALITY IN NIGERIA}

Electricity as a key infrastructure plays crucial role in advancing the development in economy, by interacting with the other sectors [4]. In other words, the provision of regular, affordable and efficient electricity is crucial for the growth, prosperity, national security as well as the rapid industrialization of any society [5]. Despite the fact that the introduction of electricity in Nigeria is over a century, the development has been at a slow rate [1]. Electricity demand in Nigeria far outstrips the supply that is very epileptic in nature, as the country is faced with acute electricity supply problems, which hinders economic development, in spite of its vast natural resources [1]. The World Bank's estimate for access to electricity in Nigeria is 55.6\% [3]. In Nigeria therefore, access to electricity is relatively low compared to other African countries [2]. For instance, (discounting population size) the figures (in percentages) are for Algeria (100), Egypt (100), Gabon (89.3), Ghana (64.1), Guinea-Bissau (60.6), Libya (100), Mauritius (100), Morocco (100), Senegal (56.5) and South Africa (85.4) [3].

Hence, according to Emodi and Yusuf [2] Nigeria's access to electricity has been below economically acceptable level and has not improved in recent times due to some obstacles. They [2] identified these obstacles to include low efficiency and performance, security of fuel source for power generation, data inadequacy, regulatory barriers, and lack of institutional arrangement, poor grid structure, dilapidated transmission and distribution network, low financial investment, lack of policy and project continuity. However, our generic name for these issues is elite insensitivity. The sector is dogged by frequent and prolonged power outages with neither apology nor explanation to the customers [9]. Earlier in this study, we had alluded to elite dilemma, whereby this class of citizens would abhor being at par with the masses, in an environment of uninterruptible electricity availability. They prefer a country in darkness. They have their personal soundproof generators in their various homes and the official versions at their work places. If sanity were to be achieved in electricity availability in the country, how would class-distinction then be demonstrated? However, the Nigerian elite also wishes that the country continued to record economic growth, without which 
the national economy would become atrophied. The dilemma of the elite is that electricity causes economic growth and economic growth causes electricity [4]. The generic elite attitude to electricity availability in this regard thus, merely borders on venal stargazing, in place of spirited action. .

Consequently, in lay literature and scholarly publications, the nature of electricity supply in the Nigeria socio-economic affairs is usually (aptly) described as being epileptic. And we argue here that it is the combination of elite unity (in infamy) and elite corruption, which led to this epilepsy. Moreover, this particular invalid belongs to a community of innumerable others to which the currently blind elite [12] seem to possess no patriotic solution. The elite policies for curing the lingering electricity ailment have rather remained multi-plural, inchoate, suffocating and truly describable as mirages. Because of this, the miraculous date of electricity for all Nigerians has continued to change. The insensitive elite policy makers have continued to change the date, first from the year 2000, to 2010 and currently, the year of the imminent encounter with the electrical Messiah is 2020. On this new date, the stupendous national resources in monetary values ostensibly sunk into spurious electricity projects would miraculously translate to megawatts of light.

It is however, only five years to the year 2020 and only $10 \%$ of the rural dwellers in Nigeria [7] have access to electricity-supply, an indication that the remainder $90 \%$ or thereabout, would have to look again in the direction of 2030 for their much-awaited salvation.

Former Chairman, Nigeria's House Committee on Power in 2007 (in the 6th House of Representatives) Ndudi Elumelu [26] argues that powerful Nigerians from all walks of life killed the power (electricity) sector. Nevertheless, the specific killers are identified in this study as the political elite, whose strategic roles in these processes are incontestable. Most Nigerians that we respect because of what they have attained in life destroyed the power (electricity) sector [26]. Elumelu further discloses:

The power sector had been used by cabals, in connivance with government officials to bleed the nation to near-death. A situation where government would spend $\$ 1.545$ billion on nine gas turbines, when 18 of same equipment were bought for $\$ 404$ million within a short period was evil and a rape of the nation's economy. From Kubwa to Katampe sub-station in Abuja, there is a transmission line. When we checked the cost of the line, we found that it was over-inflated. Then another mind-boggling discovery was made, where 18 turbines were procured for $\$ 404$ million... Then when additional nine turbines were needed, they now spent $\$ 1.545$ billion on them... The excuse they gave for such an unpardonable sin was that an African country had paid earlier for the nine turbines hence the astronomical increase of over $\$ 600 \mathrm{~m}[26]$.

This is just one of so many terrible sins committed by our powerful men in high places [26]. In the context of this study, the powerful men in high places are the political elite. In Brazil, Geometric Power spent $\$ 12$ billion to generate 12,000 Megawatts and it is working very well. At that time Nigerian government had already spent close to $\$ 16$ billion to generate between 2,500 to 3,000 Megawatts of electricity [26] which is not working well. In the Nigerian case, unregistered companies were awarded contracts and never showed up at contract sites. An affidavit with names of such companies that were awarded contracts (but never showed up) was tendered to Elumelu's committee. All the documents of the contracts were counter-signed by the former President of Nigeria (Chief Olusegun Obasanjo) who approved most of the contracts [26]. Hence, the electricity sector reality in Nigeria reflects elitist certainty and elit shenanigan. It is more of an elitemanipulated issue than matters of problematic engineering-designs and delivery.

Development is truly not an abstract concept or an esoteric contemplation. It is a peoplecentered issue, measureable by the welfare of human beings. We highlight that most recent attempts at making electricity available to Nigerian citizens have resulted in $\$ 40$ billion spent with little improvement [6]. The World Economic Forum [6] further highlights: 
In 2005, the government's Electric Power Sector Reform Act initiated a process of privatization of the power sector, to address these challenges and improve access to electricity across the country. This started with the unbundling of the single generation and distribution body in Nigeria, the National Electric Power Authority, into 18 different assets for sale to private investors - the remaining functions and assets were incorporated into the newly formed Power Holding Company of Nigeria Plc (PHCN). Last year, licenses and share certifications for all PHCN assets were sold, including generation and distribution companies. And earlier this year, the successful bidders for seven of Nigeria's gas power plants with investments worth $\$ 5.8$ billion were announced [6].

The electricity sector reality in Nigeria therefore borders on the endless display of these billions of dollars as electricity-efforts-figures. It indicates an absence of linkages with economic security and national development. Over the past few years, argues Omoju [7] reforms initiated by the government have not yielded the desired results (of economic security and national development). Substantial financial resources have been allocated to the sector but the output in terms of electricity generated has not improved; in some cases, it even deteriorated. As a result, the growth of the economy as well as the drive for industrial development, poverty alleviation and unemployment reduction (economic security) has been severely hampered [7]. National development is consequently, not evident. We further illustrate as follows:

As at today, over $56 \%$ of the Nigerian populace (Approximately 97 million people) has no access to grid electricity and those who are connected to the grid face substantial power interruptions. Systemic issues affect all phases of the power value chain, from generation to distribution, thereby forcing Nigerians to rely on self-generation. An estimated $41 \%$ of Nigerian businesses generate their own power supply, to augment the national grid supply, according to a recent World Bank Report. Nigeria lags far behind other developing nations in terms of grid-based electricity consumption, with $126 \mathrm{kWh}$ per capita. Based on Nigeria's GDP and global trends, electricity consumption should be at least five times higher than it is today [11].

According to Awosope [8] there is a very strong link between the per capita consumption of electrical power and the state of physical advancement of a nation. This means that if the energy consumed per person in a nation is very high, more industries will be working, which leads to a strong nation and this is what every right thinking citizen of any nation will want. Nevertheless, it is very sad to note that this is yet to be true in Nigeria [8]. In other words, economic security has remained disputable in Nigeria and national development has consequently remained farfetched. Nasamu [13] highlights that a recent study of power generation statistics between January and August 2015, conducted by the Power Advisory Group (within the Nigerian presidency) showed that only $25 \%$ of Nigeria's $12,522 \mathrm{MW}$ of installed capacity reaches the end user. According to Nasamu [13], widespread inefficiency means that only 3,879 MW of this capacity is operational, with 3,600 MW transmitted and 3,100 MW distributed. Most of the short fall which was about $5,381 \mathrm{MW}$, is capacity that is unavailable due to obsolete equipment and poor maintenance or to ongoing maintenance and repair activities at existing power plants. Also, about 3,262 MW is nonoperational primarily due to gas, water, high frequency, and transmission line constraints [13]. What he calls wide spread inefficiency however squarely falls under our depiction of elite insensitivity. When contracts are awarded for the replacement of obsolete equipment in the electricity sector, the contract amounts are diverted to dubious private purposes by Nigeria's corrupt elite. The Nigerian elite (the political elite) is responsible for the chaos in the electricity sector in the country. 


\section{CONCLUDING REMARKS}

It is widely accepted that there is a strong correlation between socio-economic development and the availability of electricity [1] but the electricity sector reality in Nigeria has rather come to reflect the incidence of normalcy of chaos as engineered by the elite. In this regard, in a business environment of different cottage industries, if at a point in time, none of the generating sets belonging to the different businesses is in operation, it indicates the availability of power from the general grid. This usually appears abnormal. The normal scenario is whenever the multi-numbered machines are in chaotic operation. This state of affairs also characterizes the several industrial zones in the country. Incidentally, (also) this chaos pervades the residential areas. In fact, in the residences of the less privileged, the chaos is higher, as the less privileged attempt to show the elite, whose own sets are now soundproof, that they too (the less privileged) can now own generators. We have highlighted in this study that national development and economic security are indeed inextricably interlaced. We have emphasized the relationships between the electricity sector imperatives in Nigeria, the electricity sector reality, economic security and national development. A critical governance challenge in the country hinges on the appreciation of the meaning of these linkages by the Nigerian state-actors - the political elite.

\section{References}

[1] Chukwu, P. U., Ibrahim, I. U., Ojosu, J. O., \& Iortyer, H. A. (2014). Sustainable Energy Future for Nigeria: The Role of Engineers. Journal of Sustainable Development Studies, 6(2). 242-259.

[2] Emodi, N. V., \& Yusuf, S. D. (2015). Improving electricity access in Nigeria: Obstacles and the way forward. International Journal of Energy Economics and Policy, 5(1), 335-351.

[3] The World Bank (2015). “Access to electricity". Available online at: http://data.worldbank.org/indicator/eg.elc.accs.zs.

[4] Yusuf, S. A. (2014). Energy Sector is critical to Nigeria Growth and Development: Perspective to Electricity Sub-sector in Nigeria. Online at http://mpra.ub.uni muenchen.de/55689/ Munich Personal RePEc Archive (MPRA) Paper No. 55689.

[5] Joseph, I. O. (2014). Issues and challenges in the Privatized Power Sector in Nigeria. Journal of Sustainable Development Studies, 6(1).161-174.

[6] World Economic Forum. (2015). Power sector reform in Nigeria: Attracting $\$ 10$ billion in annual investment. http://reports.weforum.org/global-energy-architecture-performance-indexreport-2015/energy-reform-in-major-emerging-economies-new-models-for-sustainedgrowth/signalling-market-readiness/case-study-iv-power-sector-reform-in-nigeria.

[7] Omoju, O. (2014). The future of Nigeria's power sector post reform. Available online at: http://www.lindau-nobel.org/the-future-of-nigerias-power-sector-post-reform/.

[8] Awosope, C. A. (2015). Nigeria electricity industry: Issues, challenges and solutions. 38th Public Lecture, Covenant University, Nigeria.

[9] Etukudor, C. Abdulkareem, A and Ayo, O. (2015). "The Daunting Challenges of the Nigerian Electricity Supply Industry”. Journal of Energy Technologies and Policy. 5(9): 25-32.

[10] Oseni, M. O. (2012) 'Households' access to electricity and energy consumption pattern in Nigeria”. Renewable and Sustainable Energy Reviews. 16(1): 990-995.

[11] Chinwuko, E.C., Mgbemena, C.O., Aguh, P.S. and Ebhota, W.S. (2011) "Electricity Generation and Distribution in Nigeria: Technical issues and solutions" International Journal of Engineering Science and Technology. 3(11): 7934-7941. 
[12] Okeke, R. C. (2014): "Anatomy of the Nigerian elite: Interrogating a blind elite model of the elite theory". European Scientific Journal. 10(4): 320-336.

[13] Nasamu, M. (2015). The Nigerian Power Sector: A Performance Appraisal under the Buhari Administration. Available at:

http://energysavers.org.ng/the-Nigeria-power-sector-a-performance-appraisal.html.

[14] Higley, J. (2010): "Elite Theory and Elites", in K. Leicht and Jenkins, J. (Eds) Handbook of Politics: State and Society in Global Perspective. New York: Springer-Verlag.

[15] Mosca, G. (1923/1939): The Ruling Class. New York: McGraw-Hill.

[16] Pareto, V. (1915/1935): The Mind And Society. A Treatise on General Sociology. New York: Dover.

[17] Michels, R. (1915/1962): Political Parties. A Sociological Study of The Oligarchical Tendencies of Modern Democracies. New York: Collier Books.

[18] Henry, N. (2001): Public Administration and Public Affairs. New Delhi: Prentice-Hall, Inc.

[19] Arowolo, D and Aluko, O. (2012): "Democracy, Political Participation and Good Governance in Nigeria", International Journal of Development and Sustainability, 1(3) 797-809.

[20] Ikelegbe, A. (1994): Public Policy Making and Analysis. London: Uri Publishing Ltd.

[21] Parry, G. (2005): Political Elites. Colchester: ECPR Press.

[22] Hacker, J. S. et al. (2012). The Economic Security Index: A New Measure for Research and Policy Analysis. www.frbsf.org/economic-research/files/wp12-21bk.pdf

[23] Bonoli, G. (2003). Social Policy through Labor Markets Understanding National Differences in the Provision of Economic Security to Wage Earners. Comparative Political Studies, 36(9), 1007-1030.

[24] Lawal, T., \& Abe, O. (2011). National Development in Nigeria: Issues, Challenges and Prospects '. Journal of Public Administration and Policy Research. 3(9): 237-241.

[25] Nwanegbo, C. J., \& Odigbo, J. (2013). Security and national development in Nigeria: The threat of Boko Haram. International Journal of Humanities and Social Science, 3(4), $285-$ 291.

[26] Ovuakporie, E. (2015). "Nigerians that we respect destroyed power sector". http://www.vanguardngr.com/2015/09/nigerians-that-we-respect-destroyed-power-sectorelumelu/. 